\author{
Maryna Saienko, \\ Sumy State University, Ukraine \\ iD ORCID ID, 0000-0003-4939-6379 \\ email:m.saienko@kmm.sumdu.edu.ua \\ Olena Hrechanychenko, \\ Sumy State University, Ukraine \\ Lesya Prasol, \\ Entrepreneur, China \\ Correspondence author: m.saienko@kmm.sumdu.edu.ua
}

\title{
MANAGEMENT IN THE PRIVATE CLINICS: IMPACT OF THE HEALTH CARE REFORMING
}

Abstract. This article aims to study the preconditions for establishing and functioning a private pediatric service in Ukraine. The authors analyzed the regulatory framework governing the private health care field. In the study framework, the authors characterized the controlling mechanism, determined the private pediatrician role in primary health care, identified the features of doing business under reforming Ukrainian medicine. The authors noted that the pediatrics service (particularly the private one) providing primary health care to children is essential for maternity and childhood care service. Thus, it is relevant to improve the work of the private pediatric service under medical reform in Ukraine. The study findings showed a decrease in the efficiency of the pediatric service in recent years due to the depletion of human, material and technical resources, problems in pediatricians training, etc. The mentioned above caused a decrease in occupational prestige and changed the pediatrician status. Despite that, the authors noted that the launching of the private doctors' offices contributed to the qualified medical care quality. Therefore, medical staff and, especially, pediatricians are considered to be important and valuable resources in providing primary children health care under outpatient treatment. The authors concluded that the proactive private pediatrician status, behaviour and real actions are significant in ensuring quality medical services. In turn, that contributes to the health care system functioning under new development conditions of Ukraine. Given reforming Ukrainian medicine, the authors highlighted the necessity to reorganize it for creating a new model providing access to the necessary health care services to all Ukrainians. Besides, this model has to ensure high-quality medical services and affordability while maintaining socially acceptable public guarantees. Therefore, the mentioned above would contribute to the sustainable development of the medical field.

Keywords: pediatrician, private doctor, health care center, clinic, health of citizens.

Introduction. For historical reasons, ambulatory care clinic determined the quality and scope of primary health care for children at all development stages of maternity and child welfare service. There has been noticed the children and adolescent's health deterioration in the last decade. Several reasons provoked the above health deterioration viz socio-economic reasons; the lack of attention to the growing generation health from the state and society; the lack of self-protection stereotypes in society; the ineffective preventive and remedial action, etc.

The ongoing medical reform in the country has resulted in new socio-economic relations. However, that caused a systemic crisis that affected the social sphere. Nowadays, there is no adequate protection of citizens' constitutional rights under changes in the health care system. Thus, At the end of the twentieth century, the health of the population, especially the socially disadvantaged, deteriorated. Notably, the maternity and child welfare service, in general, and the private pediatric service, in particular, proved to be the only ones in the health care system that prevented the collapse of women's and children's health

Cite as: Saienko, M., Hrechanychenko, O., \& Prasol, L. (2020). Management in the Private Clinics: Impact of the Health Care Reforming. Health Economics and Management Review, 2, 70-77. http://doi.org/10.21272/hem.2020.2$\underline{08}$ 
basic indicators. Moreover, they allowed reaching positive results. The private paediatrician effectiveness is determined by reducing infant and maternal mortality and children infectious morbidity.

Therefore, the paediatrician has a great impact on children and adolescents health. In the study, the research questions are as follows:

How does a paediatrician status change due to health care reform?

How would this affect his or her professional prospects?

Methodology and research methods. At the current health care development stage of Ukraine, there is the necessity for a sociological comprehension of the private paediatrician role and place in society and the role and place of a particular patient.

Thereby, the study aims to determine the paediatrician status and the private pediatric service problems to optimize its activities. The study involved the data surveys of patients' parents and public opinion from different social classes to identify the occupational outlooks to increase the occupational prestige.

Results. The pediatric service is an integral part of the maternity and childhood care service. Notably, it has effectively provided primary health care to children for many decades. However, the pediatric service's efficiency decreased in recent years due to the exhaustion of human, material and technical resources, problems in the paediatricians training (Dawes and Davison, 1994; Crawley, 1996).

Consequently, it resulted in deteriorating occupational prestige, changes in paediatricians status, the outflow of qualified personnel from the primary pediatric service, etc. It stands to emphasize that medical staff (especially paediatricians) are the most substantial medical resources providing primary children health care in the ambulatory care clinic and private medical institutions. Thus, they ensure the effectiveness of medical services. Furthermore, the proactive doctor status, his/her behavioural attitudes, and real actions ensure the medical services quality and the health care system's functioning in domestic medicine's new conditions (Volkova and Steingart, 2003).

From the above reasoning, it is clear that investigating the paediatrician status is relevant issues. The analysis of public opinion from different social classes could determine the paediatrician professional prospects. Thus, the results would allow determining the criteria for the rational use of pediatric personnel and optimize paediatrician activity, increase occupational prestige and paediatrician status, present occupational prospects.

The sociological survey results showed that $97.6 \%$ of paediatrician respondents had difficulties dealing with a child's parents, while $2.4 \%$ - with children. In turn, $61.9 \%$ of paediatricians noted the limited working length with one child, $35.7 \%$ assumed that sometimes there was enough time, and only $1.2 \%$ considered that time is always enough. Under considering the practitioners' opinions on the optimal pediatric training system, $44 \%$ of respondents believed that the system of pediatric training was optimal, $52.4 \%$ - perceived it as nonoptimal, while $3.6 \%$ of respondents - neither agree nor disagree.

The findings showed that replacing paediatricians with general practitioners is a controversial issue in the medical environment. Thus, $98.8 \%$ of paediatricians disagreed with the pediatric service's liquidation, including the private ones, to the advantage of family medicine development. Besides, this statement completely coincides with the previous researchers' data and the findings of the survey of Kyiv paediatricians (Baieva, 2008).

The majority of paediatricians (99.8\%) disagreed that physicians could master the full range of current paediatric knowledge to become paediatricians in 6 months. It stands to mention that it could affect the quality of children ambulatory care and significantly reduce the effectiveness of pediatric education in Ukraine. It was found that most of the respondents (86.3\%) considered the fact of material and economic incentives as a significant motivating factor in the work of a private paediatrician.

$35.4 \%$ of respondents didn't notice any difference in paediatrics' difficulties compared to other professions. Herewith, approximately $30 \%$ of paediatricians considered the relationship with a medical 
institution's administration to be typical professional difficulties. In turn, $21 \%$ of respondents had difficulties dealing with health authorities. On the other hand, the findings didn't show any difficulties in relations with colleagues paediatricians as typical for their profession. Therefore, that indicates a favourable psychological climate in the professional team. The answer analysis on «Other difficulties» showed that $12.3 \%$ of surveyed paediatricians pointed to a large number of reports that need to be completed, high physical and moral stress during the period of increasing morbidity, the lack of existing legislation to protect the rights of the doctor.

It was found that approximately $98.2 \%$ of paediatricians considered improving the material and technical support in their workplace as the most significant for enhancement working conditions. Herewith, fewer respondents mentioned the necessity to increase the price for private paediatrician services. That determines the need for price compliance with the level of responsibility and work intensity. $54.9 \%$ of paediatricians need more time per patient. The results concluded that the paediatricians put more value on the visit duration to provide the child's quality examination and treatment and prevention measures. Consequently, $71.2 \%$ of respondents required improving the training system for medical staff. In turn, it correlates with the recognition of the majority of paediatricians (54.2\%) that the existing system of medical training is not optimal.

The findings showed that the respondents were confused about whether to obtain the child's consent to doctors' treatment. Thus, $45.3 \%$ of respondents completely agreed, while $41.2 \%$ answered negatively. Consequently, patient informed consent remains debatable in the paediatricians' professional environment. In turn, when parents refused paediatrician treatment, most $71.2 \%$ of doctors would leave standard therapy and take a written refusal of parents, $19.5 \%$ insisted on the doctor's right to make decisions, 9.3\% considered it necessary to involve social protection authorities. In the statement «Other», $3.2 \%$ of paediatricians indicated the need to convince parents and involve lawyers to solve the mentioned above issue.

Therefore, considering the paediatricians' answers regarding the ethical and legal issues on children primary health care, it was found no legal standards considering the interests of all parties involved in the treatment process qualifying for ethical principles of paediatrics. The parents' answers confirmed that private paediatrics was a priority for the health care system of Ukraine. Despite all the critical remarks addressed to doctors, $88.3 \%$ of the surveyed patients' parents were delighted with their doctor. However, $75.1 \%$ of parents would like to choose a doctor for their child personally.

The sociological research showed that $85.5 \%$ of the respondents followed the paediatrician recommendations, $12.4 \%$ - scarcely ever follow them, while $2.1 \%$ treated under their own way. Therefore, it is possible to assume that parents trusted the professional competence of their own paediatrician. Though, it is alarm that $12.4 \%$ of respondents scarcely ever followed the attending medical doctor's recommendations.

From there, the private paediatrician is considered to be the most required highly proficient doctor. Hence, most parents are delighted with their child's doctor and believed their child was not afraid of this paediatrician. Besides, most parents always followed the paediatrician recommendations. Therefore, the above mentioned indicated the authority and high paediatrician status.

It stands to mention that paediatrician attitude and relationship with parents are the most important factors determining paediatrician status providing primary health care to children. Moreover, that depends on the amount of time the paediatrician spends examining the child and talking to parents. On the other hand, material incentives considerably determine the paediatrician motivation. Nevertheless, working conditions and logistics of the workplace is no less important factor.

Paediatricians providing primary children health care are the most important and valuable resources of medical institutions. Their proactive paediatrician status, behaviour and real actions determine the 
quality of the medical services. Besides, it ensures the health care system functioning in the new domestic medicine conditions (Batyrkhanov et al., 2019).

Formerly, it was enough to examine the child and write out a prescription to parents. Thus, the parents didn't require any doctor explanations on their child's treatment (drugs and examinations, empathy and communicative competence). However, the current patients are medicine consumers, while doctors provide services. Thus, the traditional doctor-patient relationships are changing. Patients became not only the object of medical observation but also direct participants in the treatment process. In tur, in the case of pediatric practice, parents of young patients scrutinize the matter thoroughly. Patients require detailed information, time and advertence. Moreover, it is an unacceptable lack of communication skills in paediatricians (Mehta, 2008).

The studies devoted to determining the main features the patients assess the level of pediatrician qualification showed the factor «attitude to patients» as most essential, at the second place was «patient treatment results», and then «work experience, patient feedback, personal qualities of the doctor (decency, efficiency, politeness, etc.)». It is worth noting that the indicator «doctor education» (including the degree of specialization) was ranked seventh (Reshetnykov et al., 2003).

The findings showed that a private pediatrician's successful activity depended on his/her disease progression competency, practical skills possession, and the ability to diagnose and treat. Moreover, the doctor communication skills should be good to be able to talk to patients. Therefore, nowadays, the mentioned above grows in urgency (Akanov et al., 2010).

It is appropriate to note that communication skills or communicative competencies regarding the doctor's personality are understood as a set of cognitive, emotional and behavioural features accompanying the doctor work and promoting quality contact with patients and their relatives.

It is known that professional medical activity has several specific features. On the one hand, hospital activity is characterized by many interpersonal contacts in communication with patients and their relatives. Thus, good psychological contact with the patient helps the pediatrician make the most accurate history and get a more complete and deep perception of the patient. Communication ability provides a mutual understanding and trust-based relations between doctor and patient while ensures effectively solving problems. On the other hand, a doctor's work is associated with psycho-emotional stress, high tension, the need to make decisions in conditions of lack of time, etc. Therefore, its success is determined not so much by the actual professional competencies and skills but the ability to implement them by developing an individual's professional qualities (Vasyleva, 2010).

The private pediatricians have their own communication skills such as:

- communicating with patients' parents as equal partners;

- interacting well with children to better understand their problems and concerns and get relevant information;

- explaining to the baby his/her illness and persuading to treat. Herewith, the explanation should be clear, complete and simple for the child and his parents. Treatment options should be clearly and fully described for parents to make an informed treatment decision;

- persuading parents to act according to the established treatment plan. This is especially important in long, difficult, painful, costly or culturally unacceptable child treatment procedures;

- building relationships with parents and their children based on mutual respect and trust;

- «Soft skills» to come into contact easily and inspire confidence and comfort for children and their parents during communication. Notably, soft skills are important attributes of a successful pediatrician (Barte et al., 2000).

Answering questions without hesitation, showing compassion and emotional support allows increasing the doctor's trust and authority. Thus, the mentioned above indicates the importance of communication skills in the medical staff work. Moreover, that is especially true for chronic or incurable diseases 
associated with anxiety, stress and uncertainty for the whole family. On the other hand, the constant poor communication between the doctor and parents results in dissatisfaction with the medical staff's care quality, even despite the correct diagnosis, treatment, and positive results. Notably, the lack of communication and mutual understanding often leads to discontinuation of therapy and therapeutic failures. Besides, it could cause depression and despair in children and their parents. In turn, it provokes conflicts and complaints about the health care provider.

Therefore, poor communication is a prior reason for complaints on the public and private health care system. Thus, the minority of people could judge the quality of health care based on examination, diagnosis and treatment. In turn, good communication is instrumental in ending complaints and conflicts (Yedidia et al., 2003).

For assessing and in-depth analyzing the private pediatric service of Ukraine, this study deals with the private children's office. This medical organization provides services as follows: examination, counselling and treatment for children from birth up to 18 years old; tests and rapid tests; medical procedures; registration of sickness certificates; medical examinations; individual scheduling of child vaccination. Besides, the pediatricians devote much attention to working with parents of patients. Thus, they provide monthly interviews, seminars on urgent health issues and disease prevention in children

Therefore, this study assessed the pediatrician activities and determined the quality of the services provided in a private office on the institution website using Google Forms. That allowed surveying young patients' parents.

The survey sample is 149 patients. The obtained results allowed determining the main reasons for contacting the private pediatrician. Therefore, under the first question, «What medical conditions of your child lead you to consult with a pediatrician? », the vast majority of respondents (69 people - 46\%) noted the symptoms of acute viral infection (Fig. 1).

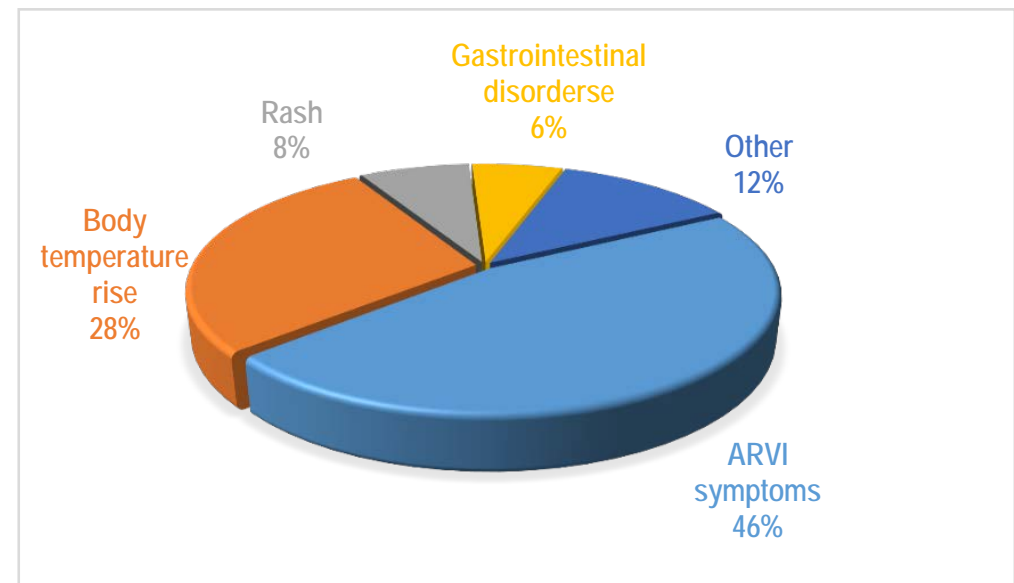

Figure 1. Answers to the first question, «What medical conditions of your child lead you to consult with a pediatrician?»

Sources: developed by the authors.

Figure 1 shows that 42 patients (28\%) recognized as such a factor in fever, 11 people (8\%) - rash, 9 patients (6\%) - gastrointestinal disorders, and $18(12 \%)$ indicated other reasons for treatment (medical examinations, vaccination, preventive consultations or other diseases).

To the second question, «Why did you visit a private pediatrician and not to a public one?» (Fig. 2), the vast majority - 103 patients (69\%) noted a convenient time to visit a doctor, 28 (19\%) - a convenient 
location for a private children's office, and 18 patients (12\%) noted other reasons, such as the doctor competency and experience, good attitude to patients, detailed and comprehensive answers to questions.

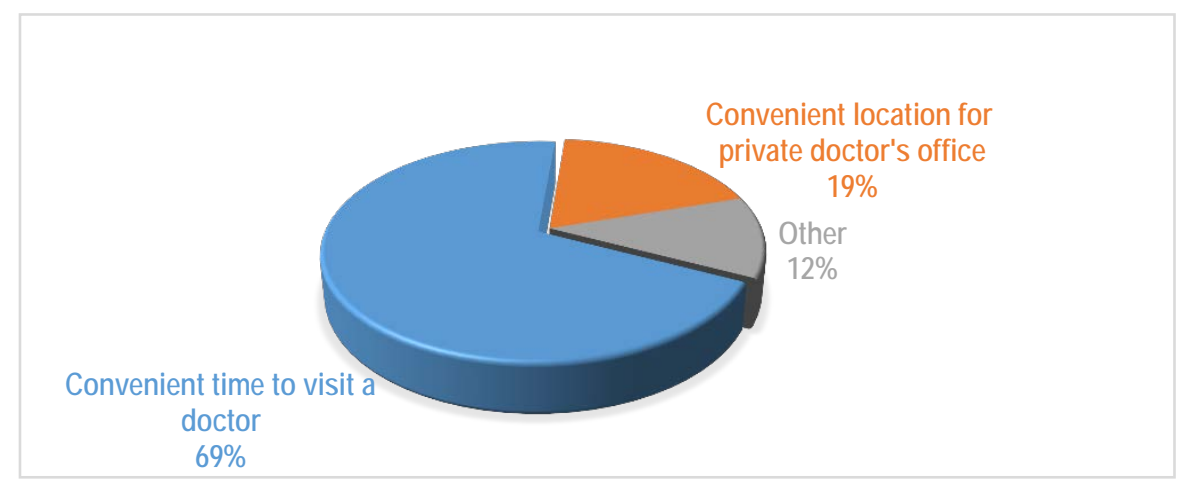

Figure 2. Answers to the second question, «Why did you visit a private pediatrician and not to a public one?»

Sources: developed by the authors.

The third question, «How did you come to hear of a private doctor's office for children?» aimed to identify the main information sources and ways for further advertising the private doctor's office for children. Figure 3 shows that 56 people (38\%) got information on the doctor's work from other parents. Thus, it indicates the quality of care and satisfaction with the pediatrician work in the vast majority of patients. In turn, 53 people (35\%) learned about the medical private doctor's office work through ads on social networks and other advertising. Finally, 40 patients $(27 \%)$ chose «Other», noting that they had a good experience dealing with this pediatrician by treating older children. Besides, some of the respondents indicated that colleagues recommended them to visit a private office.

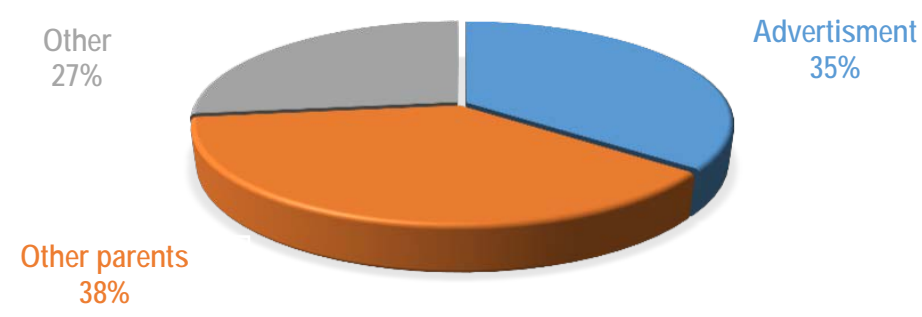

Figure 3. Answers to the third question, «How did you come to hear of a private doctor's office for children?»

Sources: developed by the authors.

The fourth question, «Your propositions on improving work of a private doctor's office for children», was open. Therefore, systematization of answers allowed identifying patients propositions, as follows:

- everything is fine;

- where possible, add laboratory services;

- telephone and online consultation; 
- concluding medical declaration;

- involving highly specialized doctors in consultations.

Given the patients' answers analysis on the above sociological survey, it is clear that the private doctor's office works on a high level. The findings show that the patients seek pediatrician treatment in different cases such as ARVI symptoms, body temperature rise in the child, gastrointestinal disorders, rashes, medical examinations, vaccination, etc. The vast majority of patients admitted the doctor's hour appointment and private doctor's office location as convenient. Besides, most respondents learned about the work of a private office from other parents. Therefore, it indicates the skilled pediatrician performance and popularity of the medical institution. The last question provided the parents' propositions which could further improve the private doctor's office work. In turn, they would be considered to formulate the recommendations to enhance pediatrician performance.

Conclusions. The statistical data shows that most doctors in Ukraine work in government institutions. Thus, they are under the control of the Ministry of Health of Ukraine or other ministries and departments. There is only a tenth part of doctors works in private medical institutions as a principal place of employment. Besides, it is worth noting that private medical employment has become more popular among some medical professionals (including pediatricians) over the past five years. In turn, the main reasons for patients to turn to private doctors are such as the need to receive medical services at a certain time, staff qualifications, emergencies, quality equipment, democratic prices, fast and accurate diagnosis, and doctors' competence and courtesy. Therefore, the model providing all Ukrainian with sufficient access to the necessary medical services is the most attractive in the health care system.

This study investigated the functional characteristics of the private pediatrician professional role. Besides, there are provided with some recommendations for improving and optimizing further pediatrics professional activity. The findings proved that the pediatric service is an integral part of the maternity and childhood care service. Moreover, it remains the effective first medico-sanitary aid for children from birth up to 18 years old. The social research findings on the private pediatrician professional activity concluded that the pediatrician attitude and relationship with parents were the most significant factors determining the doctor's status. In turn, the pediatrician motivation largely depended on material incentives. Despite that, the working conditions and material and technical support in their workplace were considered to be essential for pediatricians.

This study involved a survey of 149 patients' parents to explore the medical institution in more detail. Thus, the obtained results indicated a high performance of private children doctor's offices. Herewith, the patients seek medical in different cases such as ARVI symptoms, body temperature rise in the child, gastrointestinal disorders, rashes, medical examinations, vaccination, etc. The vast majority of patients admitted the doctor's appointment and a private doctor's office location as convenient. Moreover, it was found that most respondents learned about the work of a private office from other parents. Therefore, it indicates the skilled pediatrician performance and popularity of the medical institution.

Author Contributions: conceptualization, methodology, software, validation, formal analysis, investigation, resources, data curation, M. S., O. H. and L. P.; writing-original draft preparation, O. H.; writing-review and editing, O. H., L. P.; visualization, O. H; supervision, project administration, M. S.

Funding: This research received no external funding.

\section{References}

Akanov A. A., Akhmetov V. I., \& Abyrova M. A. (2010). Model of medical education of the Kazakh National Medical University. SD Asfendiyarov. [Google Scholar]

Baieva, O. V. (2008). Healthcare Management. Center for Educational Literature, 67-71. Retrieved from [Link] 
Bartel, D. A., Engler, A. J., Natale, J. E., Misra, V., Lewin, A. B., \& Joseph, J. G. (2000). Working with families of suddenly and critically ill children: physician experiences. Archives of pediatrics \& adolescent medicine, 154(11), 1127-1133. [Google Scholar] [CrossRef]

Batyrkhanov, Sh. K., Ymanbaeva, T. M., Karykhmanova, A. T., \& Bdullaeva, G. M. (2019). Role of the pediatrician in primary care. KazNMU, 7, 2-4. [Google Scholar]

Crawley, F. P. (1996). Ethics committees and informed consent: Locating responsibility in clinical trials. Tokai journal of experimental and clinical medicine, 22(6), 259-265. [Google Scholar]

Dawes, P. J., \& Davison, P. (1994). Informed consent: what do patients want to know?. Journal of the Royal Society of Medicine, 87(3), 149. [Google Scholar]

Mehta, P. N. (2008). Communication skills-talking to parents. Indian pediatrics, 45(4), 300. [Google Scholar]

Modern problems and prospects for the development of pediatrics in Ukraine. Retrieved from [Link]

Regulations on the organization of activity of the district pediatrician. How to choose a good pediatrician. Retrieved from [Link] Reshetnykov, A. V., Efymenko, S. A., \& Astafev, L. M. (2003). Methodology for conducting medical and sociological research. [Google Scholar]

Vasyleva, L. N. (2010). Communicative competence in the professional and personal development of a future doctor. Doctoral dissertation. [Google Scholar]

Volkova, L. I., Steingart, Yu. N. (2003). Medicine and society, physician and patient in the 21st century (new charter of medical profes-sion). Russian medical journal, 6, 9-10. [Google Scholar]

Will the services of family doctors, therapists and pediatricians be free from 2019? Corresponds to the Ministry of Health. Retrieved from [Link]

Yedidia, M. J., Gillespie, C. C., Kachur, E., Schwartz, M. D., Ockene, J., Chepaitis, A. E., ... \& Lipkin Jr, M. (2003). Effect of communications training on medical student performance. Jama, 290(9), 1157-1165. [Google Scholar] [CrossRef]

М. С. Саєнко, Сумський державний університет (Україна);

О. А. Гречаниченко, Сумський державний університет (Україна);

Л. Прасол, підприємець (Китай).

Управління приватними клініками: вплив медичної реформи в Україні

Ця стаття присвячена дослідженню передумов створення та функиіонування приватної педіатричної служби в Україні. Авторами проведено детальний аналіз законодавчої бази, що регулює діяльність приватного сектору охорони здоров'я. У ході дослідження було охарактеризовано управлінський механізм, визначено роль приватного лікаря-педіатра в первинній ланці медичної допомоги, визначено особливості ведення підприємницької діяльності в умовах реформування медичної галузі України. Автори відмітили, що педіатрична служба, в цілому, і приватна, зокрема, є складовою частиною служби охорони материнства і дитинства, яка традиційно залишається ефективною у наданні первинної медикосанітарної допомоги дітям. Таким чином, удосконалення роботи приватної педіатричної служби в умовах медичної ресрорми в Україні є актуальною темою дослідження. За результатами автори прийшли до висновку, що зниження ефективності педіатричної служби в останні роки пов'язане з вичерпанням матеріально-технічних і кадрових ресурсів, проблемами у підготовці лікарів-педіатрів. Наслідком цього стало зниження престижу професії, зміни соціального статусу лікарів-педіатрів. При цьому автори наголосили, що відкриття приватних кабінетів сприяє зростанню якост кваліфікованої лікарської допомоги. Так, в амбулаторно-поліклінічній службі, медичні кадри та, особливо, лікарі-педіатри являються значущими та цінними ресурсами при наданні первинної медико-санітарної допомоги дітям. Отримані результати засвідчили, що активна статусна позиція приватного лікаря-педіатра, його поведінкової настанови та реальні дії є визначними у забезпеченні якості медичних послуг. Таким чином, це сприяє забезпеченню функціонування системи охорони здоров'я в нових умовах розвитку України. Оскільки медична сфера України знаходиться на стаді реформування, автори наголосили на необхідності їі реорганізації та створення моделі, яка надаватиме доступ до необхідних медичних послуг всім громадянам України. До того, нова модель системи охорони здоров'я повинна забезпечувати високу якість медичних послуг та економічну доступність при збереженні соціально-прийнятого обсягу державних гарантій. Таким чином, все це сприятиме сталому розвитку медичної сорери.

Ключові слова: лікар-педіатр, приватний лікар, лікувально-профілактичний заклад, клініка, здоров'я громадян.

Manuscript received: 10.09 .2020

(C) The author(s) 2020. This article is published with open access at Sumy State University. 